\title{
System Tasks for Assessing the Regulative Impact of Legal Acts in the Entrepreneurship Sphere
}

\author{
Kunduz Zhylkychieva1, Aliya Kalybaeva², Satkynai Nasbekova3 ${ }^{3}$ Andrei Ten4, \\ Natalia Pak ${ }^{5}$, Gulsara Kuldysheva ${ }^{6}$, Zhypargul Abdullaeva $7^{*}$ (i)
}

\footnotetext{
${ }^{1}$ Department of Civil, Labor and Environmental Law, Kyrgyz National University named after J. Balasagyn, Bishkek, Kyrgyzstan ${ }^{2}$ Department of Civil Law and Procedure, Kyrgyz-Russian Slavic University named after B.N. Yeltsin, Bishkek, Kyrgyzstan ${ }^{3}$ Department of Business and Procedural Law, Kyrgyz National University named after J. Balasagyn, Bishkek, Kyrgyzstan ${ }^{4}$ Jurisprudence Program, International University of Central Asia, Tokmok, Kyrgyzstan

${ }^{5}$ Department of Jurisprudence, International Academy of Management, Law, Finance and Business, Bishkek, Kyrgyzstan ${ }^{6}$ Department of The Theory and History of Government and Law, Osh State University, Osh, Kyrgyzstan ${ }^{7}$ Science and Research Department, Osh State University, Osh, Kyrgyzstan

Email: *jypar.science@oshsu.kg
}

How to cite this paper: Zhylkychieva, K., Kalybaeva, A., Nasbekova, S., Ten, A., Pak, N., Kuldysheva, G., \& Abdullaeva, Z. (2021). System Tasks for Assessing the Regulative Impact of Legal Acts in the Entrepreneurship Sphere. Open Journal of Social Sciences, 9, 373-379.

https://doi.org/10.4236/jss.2021.94028

Received: March 16, 2021

Accepted: April 24, 2021

Published: April 27, 2021

Copyright $\odot 2021$ by author(s) and Scientific Research Publishing Inc. This work is licensed under the Creative Commons Attribution International License (CC BY 4.0).

http://creativecommons.org/licenses/by/4.0/

(c) (i) Open Access

\begin{abstract}
The article is discussing some aspects in the analysis system formation and establishment of regulatory impact in conditions of the Kyrgyz Republic. The authors examined examples from foreign experience in the application of regulatory impact analysis techniques and concluding the main tasks facing the regulatory impact analysis system in Kyrgyzstan. Research relevance in this work is focused on the analysis of regulatory impact as one of the latest tools in modern legal history optimizing government regulation and management, which are used in the vast majority of countries of the world, and which is becoming more obvious in the face of new challenges and some uncertainty in the development of the global economy, as well as focused on increasing evident in the face of new challenges and some uncertainty in the development of the global economy. Entrepreneurship is defined by demands that creating entrepreneurial opportunities and supply providing potential entrepreneurs, acting upon these opportunities. Regulatory impact analysis is considering the entrepreneurs' position when preparing regulatory documents in their development stage, those provisions that may lead to administrative or financial burdens on business or costs to the state or society as a whole.
\end{abstract}

\section{Keywords}

Analysis, Impact, Regulation, Legislation, Management, Assessment, Government 


\section{Introduction}

Regulatory impact analysis (RIA) is of the newest tools in modern legal history for optimizing state regulation and management, which is using in the vast majority of countries in the world. RIA is a comparative process, which determines the underlying regulatory objectives and identifying all the policy interventions (Hassan, 2015).

Analysis of the regulatory impact makes it possible to provide a systematic approach to the processes of introducing, changing and canceling legal norms, and as a result, to ensure a significant improvement in the regulation quality, predictability, and validity of possible changes in the regulatory framework that regulates business entities economic activities. In 2013 the Entrepreneurs Development Network summarized research results based on approaches focused on the macro level, factors influencing the level of entrepreneurship on a national level, and the micro-level, focusing on interpersonal relationships and communities in smaller geographic areas, cities, and organizations (Isenberg, 2011; Fuerlinger et al., 2015), the different approaches compared according to the geographic unit of analysis and the complexity in number of indicators.

Regulation is a fundamental governing complex, opening possibilities for society economics, where regulatory processes allow balancing competing interests and have been critical to the development of democracy and the modern government (Rodrigo, 2005). Systematization process of legislation in the sphere of entrepreneurial activity and problems associated on comparison with CIS member countries specific regulations observed laws in the field of entrepreneurship (Assetova et al., 2019).

Social entrepreneurship is one of the influencing factors in the analysis of regulative impacts acts; five dimensions around social entrepreneurship shown in Figure 1 (Cagarman et al., 2020).

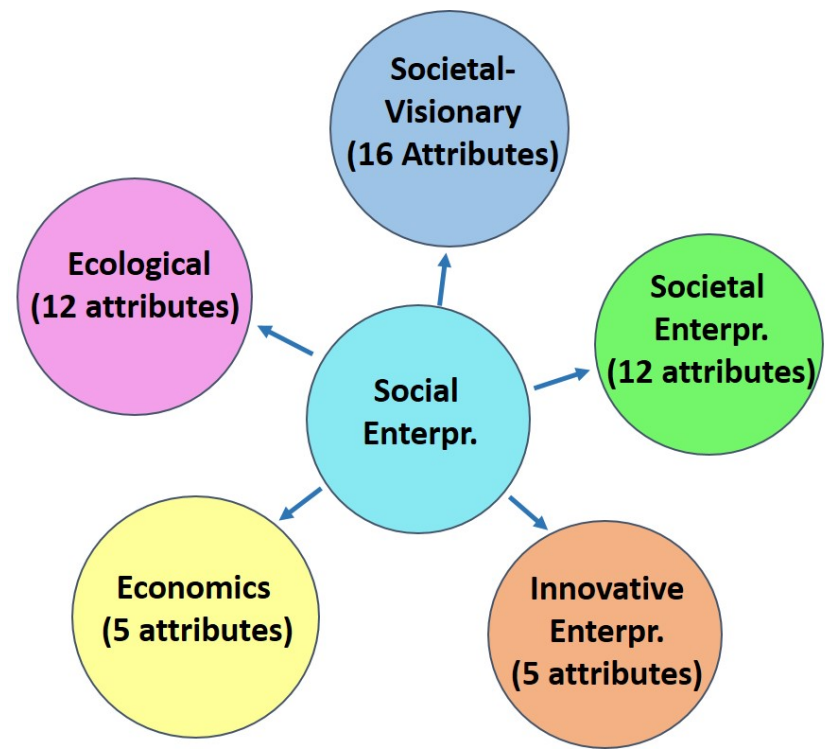

Figure 1. Five dimensions around 'social entrepreneurship' (Cagarman et al., 2020). 
In the Kyrgyz Republic, implementation of the regulatory impact analysis tool began in 2004 with the support of international donor organizations based on international experience, which suggested using analysis methodology concerning the legislative processes taking place in the country. Today, some positive indicators had been achieved, in particular, an appropriate regulatory framework has been formed, which regulates the main stages and methodology for analyzing the regulatory impact (Ministry of Justice Kyrgyz Republic, 2021).

At the same time, actual results are demonstrating the application of the regulatory impact analysis in the Kyrgyz Republic for more than ten years did not significantly improve the quality of the developed normative legal acts regulating the field of entrepreneurship. Some regulatory legal acts turned out to be insufficiently substantiated in terms of legal, anti-corruption analysis, and analysis of the impact on competition. The economic consequences quality analysis in the adopted acts also remains low. Sustainable development with the concept of multifunctional land use developed, which is simultaneously considering environmental, economic, and social aspects; facilitating assessment and governance of land use to promote sustainable development (Hamidov et al., 2016).

One of the obstacles to the effective application of the regulatory impact analysis methodology is also the lack of proper monitoring and statistical accounting of the impact of the adopted regulations on the business sector (Kovtun, 2014). The accumulated experience in the application of the analysis of the regulatory impact to the normative legal acts regulating the field of entrepreneurship made it possible to identify the problems, difficulties, and peculiarities of the application of this tool in the Kyrgyz Republic, taking into account international experience.

The entrepreneurship role is important in the institutional change and economic development (Elert \& Henrekson, 2021). Entrepreneurship can be defined through the demand that creates entrepreneurial opportunities, whereas the supply provides potential entrepreneurs, which can act upon these opportunities (Jacquemin \& Janssen, 2015). The relevance in this work focused on increasing evident in the face of new challenges and some uncertainty in the development of the global economy.

Research objectives in this work are the system tasks in assessing the regulative impact of legal acts in entrepreneurship, which are including business economic activities related to the choice of the most effective option for solving problems, calculating benefits and costs of business entities, the government, and other stakeholders, assessing the impact of regulation on the country business, climate and investment attractively, reducing risks associated with the introduction of new regulations.

\section{Research Methods}

Research design and analysis method in this work were obtained from the literature review explanations on the regulatory impacts in the entrepreneurship sphere and main tasks for analysis of the regulatory impact to solve problems 
were determined.

\section{Results and Discussions}

The literature analysis results showed that a set of institutional problems, a shortage of qualified personnel, a weak methodological base, limited information, the need to update regulatory rules and procedures in the field of regulatory impact analysis require today adequate systemic solutions to improve the quality of application of the regulatory impact analysis tool in the Kyrgyz Republic.

Organization for Economic Co-operation and Development (OECD) analysis showed that conducting RIA within an appropriate systematic framework could help to increase the governments' capacity to ensure that regulations are effective in changing world (Organisation for Economic Co-Operation and Development, 2021). According to the National Statistical Committee of the Kyrgyz Republic, the contribution of self-employed, micro, small and mid-sized enterprises in the Kyrgyz economy hopes to provide further investigations on the potential of informal entrepreneurship in Kyrgyzstan (Rudaz, 2017).

The development of the Kyrgyz Republic in the conditions of integration with the EAEU since August 2015 is a new challenge for the national economy and business entities. Some recent studies showed that the impact of regulations on the relationship between government and private businesses has been directed toward small businesses (Dixon et al., 2006). The demand for a qualitative application of regulatory impact analysis on the part of the government and business, taking into account these new challenges, is growing more and more. Therefore, the relevance in creating a unified state system to improve the quality of analysis of regulatory impact is obvious and taking into account the integration of Kyrgyzstan into the Eurasian Economic Union (EAEU), it increases many times. Resolution of the Kyrgyz Republic Government is a normative legal act adopted by the Government of the Kyrgyz Republic on the basis and for enforcement of normative legal acts that have higher legal effect (Ministry of Justice Kyrgyz Republic, 2009).

In its most generalized sense, regulatory impact analysis is a test of legislative initiatives for appropriateness and effectiveness. The analysis of the regulatory impact allows to solve the following main tasks:

1) Ensure the choice of the most effective option for solving problems;

2) Calculate the benefits and costs of business entities, the government, and other stakeholders;

3) Assess the impact of regulation on the business climate and investment attractiveness of the country;

4) Reduce the risks associated with the introduction of new regulations and increase the confidence of citizens and businesses in the decisions taken by the government.

The regulatory impact analysis tool makes it possible to take into account the position of entrepreneurs when preparing regulatory documents and to exclude, 
already at the development stage, those provisions that may lead to administrative or financial burdens on business or costs to the state or society as a whole.

In different countries, the analysis of regulatory impact can differ significantly in terms of scope (types of assessed regulation), procedure, methods of analysis, as well as terminology. For example, the term regulatory impact analysis is used in the legislation of the Kyrgyz Republic. The method of applying the analysis of regulatory impact applies to the developed and existing normative legal acts regulating the field of entrepreneurship. In international practice, this tool is named as "Regulatory Impact Analysis" (RIA), in Russian and Kazakh legislation it is an assessment of regulatory impact. In Uzbekistan, this tool is called the system of assessing the impact of legislative acts, in the Republic of Belarus the assessment of the effectiveness of the program, and in Armenia, it is the standard cost model.

In the countries of the European Union, this tool refers to the impact assessment/regulatory impact assessment, and in the Eurasian Economic Union, it is a regulatory impact analysis or regulatory impact assessment (Eurasian Economic Commission, 2021). In addition to the preliminary analysis of the regulatory impact itself, the assessment of the actual regulatory impact of regulatory legal acts is also of great importance for the adoption of high-quality regulatory legal acts and ensuring a systematic approach to determining their potential and actual impact on entrepreneurship. It is a tool designed to assess the actual results of achieving regulatory goals in relation to those declared when adopting regulatory legal acts. Such an assessment, as a rule, carried out on the key legal acts for businesses sometime after their adoption. An assessment of the actual regulatory impact allows:

1) Determine and evaluate the actual positive and negative consequences of the adoption of a regulatory legal act;

2) To identify provisions in the normative legal act that unreasonably impede the conduct of entrepreneurial and other economic activities or lead to the occurrence of unreasonable budget expenditures;

3) Give recommendations on the advisability of maintaining, changing, or canceling the current regulatory legal act.

\section{Conclusion}

In summary, the analysis of the regulatory impact and assessment of the actual regulatory impact was determined as integral components in the government system regulation of the business sphere, since their methodology allows not only to predict the possible consequences of the particular normative act adoption, but also to track law enforcement practice to assess the quality of adopted acts. The analysis of regulatory impact in various countries is significantly different in types of assessed regulation, procedure, methods of analysis and terminology. Research implications are solutions for regulatory impact analysis tasks, determination and evaluation of the actual positive and negative consequences, 
identification of provisions in the normative legal act impeding the conduct of entrepreneurial and other economic activities, and recommendations.

\section{Conflicts of Interest}

The authors declare no conflicts of interest regarding the publication of this paper.

\section{References}

Assetova, G., Kuebeyev, Y., \& Kizdarbekova, A. (2019). Problems of Legislation Systematization in the Sphere of Entrepreneurial Activity. Journal of Advanced Research in Law and Economics, 9, 2239-2247.

Cagarman, K., Kratzer, J., \& Osbelt, K. (2020). Social Entrepreneurship: Dissection of a Phenomenon through a German Lens. Sustainability, 12, 7764. https://doi.org/10.3390/su12187764

Dixon, L., Gates, S. M., Kapur, K., Seabury, S. A., \& Talley, E. (2006). The Impact of Regulation and Litigation on Small Business and Entrepreneurship. WR-317-ICJ, Santa Monica: RAND Institute for Justice, $81 \mathrm{p}$.

Elert, N., \& Henrekson, M. (2021). Entrepreneurship Prompts Institutional Change in Developing Economies. The Review of Austrian Economics, 34, 33-53. https://doi.org/10.1007/s11138-020-00501-0

Eurasian Economic Commission (2021). Report on the Implementation of the Main Directions of Integration within the Eurasian Economic Union for 2018.

http://www.eurasiancommission.org/ru/Documents/Forms/AllItems.aspx

Fuerlinger, G., Fandl, U. \& Funke, T. (2015). The Role of the State in the Entrepreneurship Ecosystem: Insights from Germany. Triple Helix, 2, Article No. 3.

https://doi.org/10.1186/s40604-014-0015-9

Hamidov, A., Helming, K. \& Balla, D. (2016). Impact of Agricultural Land Use in Central Asia: A Review. Agronomy for Sustainable Development, 36, Article No. 6. https://doi.org/10.1007/s13593-015-0337-7

Hassan, K. (2015). Regulatory Impact Analysis in Legal Research: Way Forward for Malaysian Legislation. Mediterranean Journal of Social Sciences, 6, 520-524. https://doi.org/10.5901/mjss.2015.v6n3p520

Isenberg, D. (2011). The Entrepreneurship Ecosystem Strategy as a New Paradigm for Economic Policy: Principles for Cultivating Entrepreneurship. Dublin: Institute of International and European Affairs.

Jacquemin, A., \& Janssen, F. (2015). Studying Regulation as a Source of Opportunity Rather than as a Constraint for Entrepreneurs: Conceptual Map and Research Propositions. Environment and Planning C: Government and Policy, 33, 846-862. https://doi.org/10.1068/c11180b

Kovtun, Z. L. (2014). On the Methodology for Studying the Regulatory Impact of Law // Gaps in Russian Legislation. Legal Journal, 2, 72-73.

Ministry of Justice Kyrgyz Republic (2009). Law of the Kyrgyz Republic on Normative Legal Acts of the Kyrgyz Republic (pp. 1-17). No. 241, Bishkek: Government of Kyrgyz Republic. http://cbd.minjust.gov.kg/act/view/ru-ru/202591

Ministry of Justice Kyrgyz Republic (2021). Methodology for Analyzing the Regulatory Impact of Regulatory Legal Acts on the Activities of Business Entities, Approved by the Government of the Kyrgyz Republic September 30, 2014 No. 559.

http://cbd.minjust.gov.kg/act/view/ru-ru/97019 
Organisation for Economic Co-Operation and Development (2021). Regulatory Impact Analysis: Trend in RIA Adoption across OECD Jurisdictions.

https://www.oecd.org/regreform/regulatory-policy/ria.htm

Rodrigo, D. (2005). Regulatory Impact Analysis in OECD Countries Challenges for Developing Countries. In Organization for Economic Cooperation and Development (Ed.), South Asian-Third High Level Investment Roundtable (33 p.). Paris: Organization for Economic Cooperation and Development.

Rudaz, P. (2017). The State of MSME Development in Kyrgyzstan. Working Paper Series on Informal Markets and Trade, No. 3, 1-19. urn:nbn:de:hebis:30:3-415188. 